CS A. Grønn \& I. Marijanovic (eds.) Russian in Contrast, Oslo Studies in Language 2(2), 2010. 339-

\title{
CONTRASTIVE LEXICOGRAPHICAL PERSPECTIVES ON THE RUSSIAN LANGUAGE
}

\author{
OLGA IVANISHCHEVA \\ Murmansk State Pedagogical University
}

\section{ABS TRACT}

The article is devoted to the problems of the representation of culture elements in a bilingual dictionary. It is shown that cultural information concerning realia is necessary in dictionary definitions. Facts about different types of realia may be included as additional information after the actual translation.

\section{[1] INTRODUCTION}

The present article is devoted to the problem of the representation of culture elements in a bilingual dictionary.

The research hypothesis is as follows: during lexicographical processing of culture elements in a bilingual dictionary, the selection of information should be defined by cognitive and contrastive principles in order to determine the knowledge of a dictionary user and help the people of two different cultures understand each other. In connection with the hypothesis put forward, we seek to develop a theory of representation of cultural information in a bilingual dictionary.

The article focuses on the following issues:

- The need for the representation of cultural information in bilingual dictionaries in order to provide additional and necessary information to the translation.

- The strategies concering the inclusion of cultural information, as additional commentary relevant to the translation in bilingual dictionaries.

\section{[2] CULTURE ELEMENTS}

By culture elements relevant for a bilingual dictionary, we understand the socalled realia, i.e. a culture-specific vocabulary, that is, a vocabulary with a cultural component of meaning, lexical and phraseological units denoting realia specific for a certain culture, such as artifacts, aspects of social life, and historical events. In other words, a kind of vocabulary which demands further commentary because the denotatum (object) is highly specific for a certain culture. 
In our research, phrases denoting facts of non-verbal behaviour are also included in the group of such realia, e.g. ни пуха ни пера (literally: neither down, nor a feather; Good luck); не сглазить бы (Knock on wood!); с первым апреля (April Fools). We consider nomenclature names (е.g. валерьянка (valerian drops), индийский чай (Indian tea), ливерная (liverwurst), докторская колбаса (literally: doctor's sausage), cigarettes “Казбек” (Kazbek) and "Беломорканал” (Belomorkanal), shops “Детский мир” (literally: Children's World, Detskij Mir)) and phrases with cultural connotations as a separate group (е.g. десять лет без права переписки (ten years of prison without the right to write letters), московские кухни (Moscow kitchens), пятая графа ("the fifth column")) as a separate group.

\section{[3] DICTIONARY USER}

One of the most remarkable tendencies of modern lexicography is the appeal to the dictionary user. As repeatedly mentioned in linguistic research, the issue of creating an active dictionary is becoming more and more important. For example, L.V. Shcherba emphasizes that it is necessary to have two explanatory translation dictionaries for each pair of languages: for Russians with explanations in Russian and for non-native Russian speakers with explanations in corresponding languages. According to L.V. Shcherba, these four dictionaries would allow a nonnative speaker to read and understand books in the original language, as well as to grasp the authentic meaning of foreign words (Shcherba \& Matusevich 1993, 7).

The main task of a passive dictionary is to provide word meanings. In certain contexts, the reader can find the necessary translation on his/her own using her native language. In an active dictionary, the reader does not search for the explanation of the word to be translated (he/she knows it already) but for instructions helping him/her to find an exact equivalent in the target language (Gak 1995, 53).

The issue concerning the "amount of cultural "connotation" in a bilingual dictionary" has repeatedly been brought up by V.P. Berkov (see e.g., Berkov (1975) and Berkov (2004)). Berkov points out that all serious dictionaries include some linguistic and cultural knowledge. But the way this knowledge is represented is not systematic. Some cultural phenomena should be extensively commented on, including the differences and similarities which exist in different cultures (Berkov 1975, 418).

Bilingual dictionaries usually do not include any cultural information. See, for example, the words relating to the realia of Russian history and culture in Russian-Foreign language dictionaries: Бурлак (Burlak) - pramdrager (Berkov 1994); barge hauler (Smirnickij 1991); Treidler (Lejn 1989); Белогвардеец (Belogvardeec) - vitgardist (Davidsson 1992); hvitegardist (Berkov 1994); White Guardsman (Ozieva et al. 1995); White Guard (Smirnickij 1991); Weißgardist, Konterrevolutionär (Lejn 1989). 
The absence of information in bilingual dictionaries often precludes a nonnative speaker from understanding Russian texts in a correct way. Consider the following example:

(1) Создана цепкая система переливающихся сосудов - личных связей, взаимной выручки, сплетенных между собой интересов. Гражданский и Уголовный Кодексы не стоят и гривенника, если раздастся звонок из горкома или райкома. Либо из некоей грозной конторы.

(Зорин Л. Трезвенник, Знамя. 2001(2))

Such texts raise questions non-native speakers cannot find answers to in dictionaries. So, from the definition of the word горком or its translation (bykomité town committee (Berkov 1994)), it is not clear why the integrity of the law collapses when a call comes from the town committee.

We have a similar example with one other type of realia of the Soviet times, namely the magazine Юность (Junost'), which features in N. Baranskaja's novel "Week after Week", translated into Swedish by K. Hansson. The translator translates the name of the magazine Юность as tidskriften "Junostj" without explaining the role this magazine played for a Soviet reader (N. Baranskaja wrote her novel in 1969):

(2) Когда мы утрясаемся немного, мне удается вытащить из сумки “Юность”. Читаю давно всеми прочитанную повесть. (Baranskaja 1981) Jag läser Aksjonovs berättelse "Tomma tunnor", som varenda människa läst för länge sedan. (article's author emphasis). (Swedish translation by Hansson)

The meaning of the original sentence remains unclear for a non-native speaker. Literally, the Swedish translation says: "I am reading Aksenov's novel "Zatovarennaya bochkotara" ("Overstocked cask") (in Swedish literally "Empty casks"), which has already been read by everybody".

The translator uses the author's name and the name of the novel in the text because of the role the magazine Юность played in the social and cultural life of those times and because of the importance of the year in which Aksenov's novel emerged (i.e. 1968). But this does not reveal the meaning the magazine and the novel have for a Russian native-speaker and moreover for a contemporary of $\mathrm{N}$. Baranskaja. For example, it is difficult to explain to a non-native speaker that even mentioning Aksenov's name could cause problems with publishing a novel. Creating a system of methods of lexicographic analysis demands a theoretical approach to the problem of representation of culture elements of this kind in bilingual dictionaries, at the same time the volume of this information must obviously be kept at a minimum. 
The selection of cultural information to be included in a bilingual dictionary should be guided by the following cognitive and contrastive principle: a bilingual translation dictionary ought to explain the things that a native speaker knows, but not to explain the things that a dictionary user (i.e. a non-native speaker) knows.

\section{[4] SWEDISH-ENGLISH-RUSSIAN EXAMPLES}

The Swedish word "dagmamma" means a kindergarten teacher, while "dagbarn" can be defined, according to (Malmström et al. 1994), as a child ("dagbarn" literally is a "day child") left in another family for the day under the supervision of a teacher while its parents are at work. For a Russian native-speaker, it is not clear what the terms are which regulate the child's stays in the family and how much the family is paid for doing that. While searching for an English translation, one can find out that "dagmamma" (eng. baby-minder, child-minder) is a person paid for looking after a child more often at his/her home while both parents are at work. In Great Britain, designated services make sure that the premises are acceptable and the child-minder meets the necessary standards (DELC 1992). The dictionary (Apresjan \& Mednikova 1999) suggests that "baby-minder" has the following meaning: приходящая няня (часто школьница или студентка), остающаяся с детьми за плату. The meaning of the word "child-minder" is: приходящая няня или 1) няня в яслях; 2) воспитательница (детского сада).

So, for example, for an English native-speaker "dagmamma" is a familiar concept and can be translated, though it is necessary to specify that "dagmamma" is a nurse (private or municipal). A municipal nurse is a woman employed by a municipality to organize a family kindergarten ("familjedaghem" in Swedish). The word "kindergarten" has a different meaning here since a "familjedaghem" is organized for children from 6 months to 12 years during the time the parents are at work or are studying and the children are not at school (Juridik till vardags 1993: 410-411). For a Russian-speaking dictionary user (there is no such word in Russian (Milanova 1992)), the word belongs to the group of realia without equivalents. It can hardly be called culture-specific because working mothers in Russia have always been helped by grandmothers or nurses who either came home to a child (so-called "coming babysitters"), or a child was taken home to them because of the reduced quantity of kindergartens. Thus the Swedish "dagmamma" cannot be considered as a culture-specific word or a word with background meaning (Denisova 1978). Distinctive features of realia should be given as comments taking into account the level of a non-native speaker's knowledge.

In this paper, the contrastive principle of material selection assumes that any information concerning realia will contain nationally specific data and their specificity in a bilingual dictionary should be determined by comparing such data to another language or another culture. 
In the works on translation theory, one can observe that the typological analysis of the lexicon on the basis of the componential analysis is a widely used research method when dealing with the "cultural" lexicon. The method compares semes present in one equivalent and absent in another, a method which was established in the works of N.I. Tolstoy, see (Tolstoj 1997, 21).

In our approach, we also take into account the background knowledge of an average native speaker, i.e. a native-speaker of a given language and given culture with secondary education.

In lexicographic theory connected to translation and teaching of foreign languages, the concept of reconstruction of background knowledge has a different meaning. The main task of bilingual lexicography with regard to the culturespecific lexicon consists in selecting the minimum of information (provided as a comment) necessary to understand and use the words of another language. The problem of defining the content of such a comment and consequently of its minimization is in fact the problem of choosing the distinctive features that should be mentioned in a bilingual dictionary.

It is obvious that only the features that distinguish the given object or that are very important for the public life should be represented in a bilingual dictionary. Not everything that a native speaker knows about an object or that is associated for him/her with this object is relevant for a non-native speaker.

It is to be emphasized that, for example, definitions of a Russian word in a Russian-German dictionary will be in many cases different when compared to the definition of the same word in a Russian-Polish or a Russian-Vietnamese dictionary (Sternin 1992, 215).

\section{[5] RUSSIAN-SWEDISH-NORWEGIAN-CZECH EXAMPLES}

Our analysis of the Russian-Norwegian (Berkov 1994), Russian-Swedish (Davidsson 1992) and Russian-Czech (Vlchek 1985) dictionaries has shown that a Russian culture-specific word requires different comments in different dictionaries, i.e. various explanations to translation should be present in a dictionary definition.

For example, Baba-Yaga (Баба-яга) as a character from fairy tales is translated as Baba-Yga, which requires certain comments for Swedish and Norwegian native-speakers similar to the one given in (Berkov 1994): "gammel heks i slavisk mytologi; bortfører og fortœrer barn, flyr i en morter, utvisker sine spor med en kost, bor i urskogen i en "hytte på hønebein"”' (an old witch in Slavic mythology who steals and eats children, flies on a mortar, wipes out her tracks with a broom, lives in the woods in a "hut on chicken legs"). Compare this to (Davidsson 1992): "trollgumma (häxa) i ryska folksagor" (a witch in Russian fairy tales), where the comment does not provide sufficient information for a Swedish native-speaker. A Swedish native-speaker sees "häxa" (witch) as a woman with supernatural abilities which she uses to harm people. 
For a Russian native-speaker, Baba Yaga is, according to a standard definition, rather the following: безобразная старуха-колдунья, передвигавшаяся в ступе и заметающая след помелом (хозяйка леса, повелительница его обитателей, вещая старуха, страж входа в царство смерти, живущая в дремучем лесу в избушке на курьих ногах), помощница героя. Thus in a Russian-Swedish dictionary, the comment on translation should be, in our opinion, as follows: "an ugly old woman who reigns over witches and other evil spirits, lives in the woods in a hut on chicken's legs, flies on a mortar, and wipes out her tracks with a broom; she lures heroes of fairy tales (especially children) to her hut where she roasts them in a stove by throwing them into it with a spade".

Other comments are needed for a Czech native-speaker. Knowing that Бабаяга is not only a character in Russian fairy tales but also a hero in Slavic mythology, we can assume that the comment directed at Swedish native-speakers will be redundant for a Czech native-speaker. The only thing that distinguishes the Czech Baba Yaga from the Russian one is that she is wicked and never helps the heroes. So, the comments to the Czech translation can be as follows: "in Russian fairy tales, Baba Yaga is sometimes a hero's helpmate; she favours heros and gives them advice."

\section{[6] CONCLUSION}

A contrastive definition analysis, i.e. the comparison of definitions of the same words in explanatory dictionaries of different languages, helps us to select the elements of cultural information necessary in a bilingual dictionary for a certain pair of languages. The analysis is aimed to show how a mastered word, as a sign of realia, reflects the knowledge of native speakers about a foreign culture element.

Culture-specific differences between words can be revealed by means of other methods as well (i.e. sociolinguistic methods, like interrogations; associative experiments; introspection (if the author of the dictionary is a native-speaker of a given language); through analysis of fiction, newspaper and magazine articles).

Realia features can vary greatly, and the selection of concept features can sometimes be subjective. It cannot be explained either by the dictionary type, or by the vocabulary category. Which features of realia should be represented in the comments in a bilingual dictionary? According to V.P. Berkov, a dictionary entry should contain two main components: the description of REALIA and description of its FUNCTION. Sometimes the SYMBOLIC MEANING of realia must also be represented (Berkov 2004, 163).

Taking into account the cultural value of a feature we select, the following elements of realia description should be, in our opinion, present in a bilingual dictionary: a) attributes (appearance, components, traditions); b) historical markedness; c) social status (functions); d) function (purpose, role); e) popularity / unpopularity of realia; f) symbolic meaning. 


\section{REFERENCES}

Apresjan, Ju.D. \& Je.M. Mednikova. 1999. Novyj bol'shoj anglo-russkij slovar': v 3 t.; 3-e izd. Moskva.

Berkov, V.P. 1975. Slovar' i kul'tura naroda. In Masterstvo perevoda, vol. 10, Moskva.

Berkov, V.P. 1994. Russisk-norsk ordbok: 2. utgave. Oslo.

Berkov, V.P. 2004. Dvujazychnaja leksikografija: Uchebnik; 2-e izd. Moskva.

Davidsson, K. 1992. Russko-shvedskij slovar'. Stockholm.

DELC. 1992. Longman Dictionary of English Language and Culture.

Denisova, M.A. 1978. Lingvostranovedcheskij slovar'. Moskva: Narodnoe obrazovanie v SSSR.

Gak, V.G. 1995. Dvujazychnyj slovar' aktivnogo tipa. In Jazyk-sistema. Jazyk-tekst. Jazyk - sposobnost', Moskva.

Lejn, K. 1989. Russko-nemeckij slovar' (osnovnoj): 10-e izd. Moskva.

Malmström, S., I. Györki \& P. Sjögren. 1994. Bonniers svenska ordbok. Stockholm.

Milanova, D.Je. 1992. Shvedsko-russkij slovar'. Stockholm.

Ozieva, A., O. Stott \& M. Hepburn. 1995. Collins Russian-English English-Russian Dictionary.

Shcherba, L.V. \& M.I. Matusevich. 1993. Russko-francuzskij slovar': 14-e izd. Moskva.

Smirnickij, A.I. 1991. Russko-anglijskij slovar': 16-e izd. Moskva.

Sternin, I.A.1992. Nacional'naja specifika znachenija slova i leksikografija. In V.V. Dubichinskogo, S.V. Vakulenko \& A.I. Danilenko (eds.), Sovremennye problemy leksikografii, Har'kov.

Tolstoj, N.I. 1997. Slavjanskaja leksikologija i semasiologija, izbr. tr. t.1. Moskva.

Vlchek, J. 1985. Russko-cheshskij slovar': 3-e izd. Moskva. 
AUTHOR CONTACT INFORMATION

Olga Ivanishcheva

Department of Intercultural Communications and Language Theory

Murmansk State Pedagogical University

Russia

oivanishcheva@gmail.com 